\title{
The contribution of the Guarulhos Municipality (São Paulo State) to the wa- ter quality of the Alto Tietê System
}

\author{
Reinaldo Romero VARGAS, João José Samarão GONÇALVES, Fabrício Bau DALMAS, Antonio Ro- \\ berto SAAD, Regina de Oliveira Moraes ARRUDA \& Anderson Targino da Silva FERREIRA
}

Programa de Pós-Graduação em Análise Geoambiental. Universidade Guarulhos. Praça Tereza Cristina, 229, Centro, CEP 07023-070, Guarulhos, SP, Brasil (rvargas@prof.ung.br, jsgoncalves@prof.ung.br, fdalmas@prof.ung.br, asaad@prof.ung.br, rarruda@prof.ung.br, atargino@prof.ung.br).

Recebido em 03/2016. Aceito para publicação em 12/2016.

Versão online publicada em 08/05/2017 (www.pesquisasemgeociencias.ufrgs.br)

\begin{abstract}
The population growth in Guarulhos (São Paulo State) has been above the average for the São Paulo Metropolitan Region (RMSP). The Baquirivu-Guaçu River Basin (BHRBG), where the Baquirivu-Guaçu River is located, is exactly the urban expansion vector of Guarulhos municipality and neighboring areas. This study presents an analysis of the quality of the Baquirivu-Guaçu River waters at the entrance and at the exit of the Guarulhos municipality, in order to assess the effects of the implementation of sewage treatment plants (STPs) and land use on the Baquirivu-Guaçu River water quality between 2010 and 2014. For that were prepared the land use maps in the period analyzed, an analysis of the functioning of STPs in the study area, a statistical analysis of the Water Quality Index (WQI) and its parameters at different points of the river. The data relative to the Baquirivu-Guaçu River physico-chemicals and microbiological analyses indicate a much lower water quality in the exit of the Guarulhos municipality (WQI=16), when compared to that coming from the Arujá municipality (WQI=32). The mean values highlighted for BOD, DO, TU, TS and FC parameters indicate a considerable worsening of the Baquirivu-Guaçu River waters at point BQGU 03850. The values of TN, TP and pH parameters both at the entrance and exit of the basin are close. The analysis of land use evolution and water quality shows the consequences of an improper process of urban growth in the basin and that the domestic and industrial polluting sources represent considerable risk to water quality, attesting that the sanitation works carried out up to now have not been effective in reducing the polluting charges launched in the Baquirivu-Guaçu River waters. Keywords: Baquirivu-Guaçu River Hydrographic Basin, Sewage Treatment Plant, Urban Waters, WQI.
\end{abstract}

Resumo: A contribuição do município de Guarulhos (Estado de São Paulo) para a qualidade de água do Sistema Alto Tietê. Guarulhos (SP) tem apresentado índices de crescimento populacional acima da média da Região Metropolitana de São Paulo (RMSP). A Bacia Hidrográfica do Rio Baquirivu Guaçu (BHRBG), onde se localiza o Rio Baquirivu Guaçu, é o vetor de expansão urbana do município e da região. Este trabalho apresenta uma análise da qualidade das águas do Rio Baquirivu-Guaçu na entrada e na saída do município de Guarulhos, avaliando os efeitos da implantação das ETEs e do uso da terra sobre a qualidade das águas do Rio Baquirivu-Guaçu, entre os anos de 2010 e 2014. Para isto foram elaborados os mapas de uso de terra no período analisado, uma análise do funcionamento das ETEs na área de estudo, e a análise estatística dos Índices de Qualidade de Águas (IQA) e de seus parâmetros nos diferentes pontos do rio. Os dados referentes às análises físico-química e microbiológica do Rio Baquirivu-Guaçu indicam uma qualidade de água na saída do município de Guarulhos (IQA=16), muito inferior àquela que recebe do município de Arujá (IQA=32). Os valores médios, em especial para os parâmetros DBO, OD, TU, ST e CF indicam uma piora na qualidade das águas do Rio Baquirivu-Guaçu no ponto BQGU03850. Os valores dos parâmetros NT, PT e pH foram muito próximos para ambos os pontos da entrada e saída da bacia. A análise entre a evolução do uso da terra e a qualidade da água demonstra as consequências do processo inadequado de crescimento urbano na bacia e que as fontes poluidoras domésticas e industriais representam considerável risco à qualidade das águas, demonstrando que as obras de saneamento realizadas até o momento não foram eficazes na redução de cargas poluidoras das águas do rio Baquirivu-Guaçu.

Palavras-chave. Bacia Hidrográfica do Rio Baquirivu-Guaçu, Estação de Tratamento de Esgoto, Águas Urbanas, IQA 


\section{Introduction}

Rivers, or water courses, have been one of the most important resources for the survival of the human species. Water is collected from them for consumption, production of food and inputs for the economy, and soil irrigation for planting for both subsistence and large-scale agriculture. As agriculture methods developed, man settled near the riverbanks, where soil fertility was greater and food became more available and small agglomerations were created, which soon grew to villages and cities.

Quality of life, ecosystem functions and economic development depend on water volumes and global and local availability. Thus it is fundamental to consider availability and global, regional and local water demand to build trustful scenarios that make the implementation of consistent management policies possible in the future. Water demands are increasing due to population growth and urbanization, to the fast increase of water extraction from rivers, lakes and reservoirs and aquifers, producing local, regional and continental problems (Tundisi et al., 2006). When it comes to the urban space, the river conforms an element that integrates the landscape, and usually the inhabitants incorporate it as a landmark. In turn, the expansion of the city area and the intensification of the urban occupation and use makes causes a strong impact on the hydrographic basin. This, together with the equipment installed on river banks, causes impact on the natural environment, producing deteriorated spaces and leading to the elimination of the riparian forest, which is an element essential to the preservation of the equilibrium of both biota and physical space.

The São Paulo Metropolitan Region (SPMR) is one of the areas that have undergone a fast development process in the last years, attracting an increasing and disorderly occupation, at the same time that it causes, as a consequence, an uncontrolled increase of the urbanization rate, with severe environmental impacts. In this same context, Guarulhos, one of the municipalities that constitute SPMR, has five hydrographic basins. The Baquirivu-Guaçu River Hydrographic Basin (BGRHB) is the largest of them and serves mostly the urban area and consequently, the increasing and disorderly occupation (Andrade et al., 2008). According to Diniz \& Duarte (1996), the spring of the Baquirivu-Guaçu River is $790 \mathrm{~m}$ high and located in the Jardim do Trevo, in Arujá, and its mouth is $724 \mathrm{~m}$ high, located in the Várzea do Palácio, in Guarulhos. The difference in altitudes ( $66 \mathrm{~m})$, divided by an approximately $38 \mathrm{~km}$-long course, results in a mean gradient of $1.73 \mathrm{~m} . \mathrm{km}^{-1}$.

The sewage treatment in Guarulhos is a process that started in 2010. According to the data presented by SAAE (Autonomous Service of Water and Sewage), a significant amount, approximately $70 \%$ of the Guarulhos sewage, is still discharged, with no treatment, in BGRHB (PMG, 2014). With an urban population exceeding 1.3 million, 84\% of the sewage produced in the Guarulhos municipality was collected in 2014 and only $1.38 \%$ was treated (CETESB, 2014). In 2015, the municipality has three sewage treatment plants (STP), namely São João, Bonsucesso and Várzea do Palácio, all of them serving the neighborhoods that belong to BGRHB (PMG, 2014).

The objective of this paper is to present an analysis of the contribution of Guarulhos municipality to the water quality of the Baquirivu-Guaçu River, by means of physico-chemical and microbiological analyses of the river waters. The analyses of the Baquirivu-Guaçu River waters at the entrance of Guarulhos municipality (BQGU03150), coming from municipality de Arujá, and at the exit (BQGU03850) are presented, in order to assess land use aspects, and also the effects of the implementation of STPs on the Baquirivu-Guaçu River water quality.

\section{Area, materials and methods}

\subsection{Characterization of the physical space}

The Baquirivu-Guaçu River Hydrographic Basin (BGRHB) is the second largest basin in the Alto Tietê System urban area, the Tamanduateí River basin $\left(320 \mathrm{~km}^{2}\right)$ being the largest. The BGRHB portion in Guarulhos covers $149 \mathrm{~km}^{2}$, which represents $47 \%$ of the total area of the municipality. BGRHB has significant remnants of floodplains and forests in the north, from where the BGRHB affluents flow (Diniz \& Duarte, 1996). These authors and later Andrade et al. (2008) and Campos (2011), state that the Baquirivu-Guaçu River basin (Fig. 1) is located in the Planalto Atlântico Province. Those authors identified two structural macrocompartments separated by the NE-trending Jaguari River fault. The relief is relatively flat in the southern portion of the Baquirivu-Guaçu River basin, where hills and fluvial plains predominate; in the northern portion the relief is rugged, with expressive elevations in the Itaberaba and Bananal ridges.

Metamorphic and igneous rocks predomina- 
te in this portion, whereas in the southern portion deposits of the São Paulo Sedimentary Basin and BGRHB Quaternary sediments occur. Drainage patterns are also distinct, in the northern portion being dendritic, constituting watershed areas. The main characteristics of the BGRHB physical space are listed in Chart 1.

\section{$\underline{\text { São Paulo Metropolitan Region }}$}

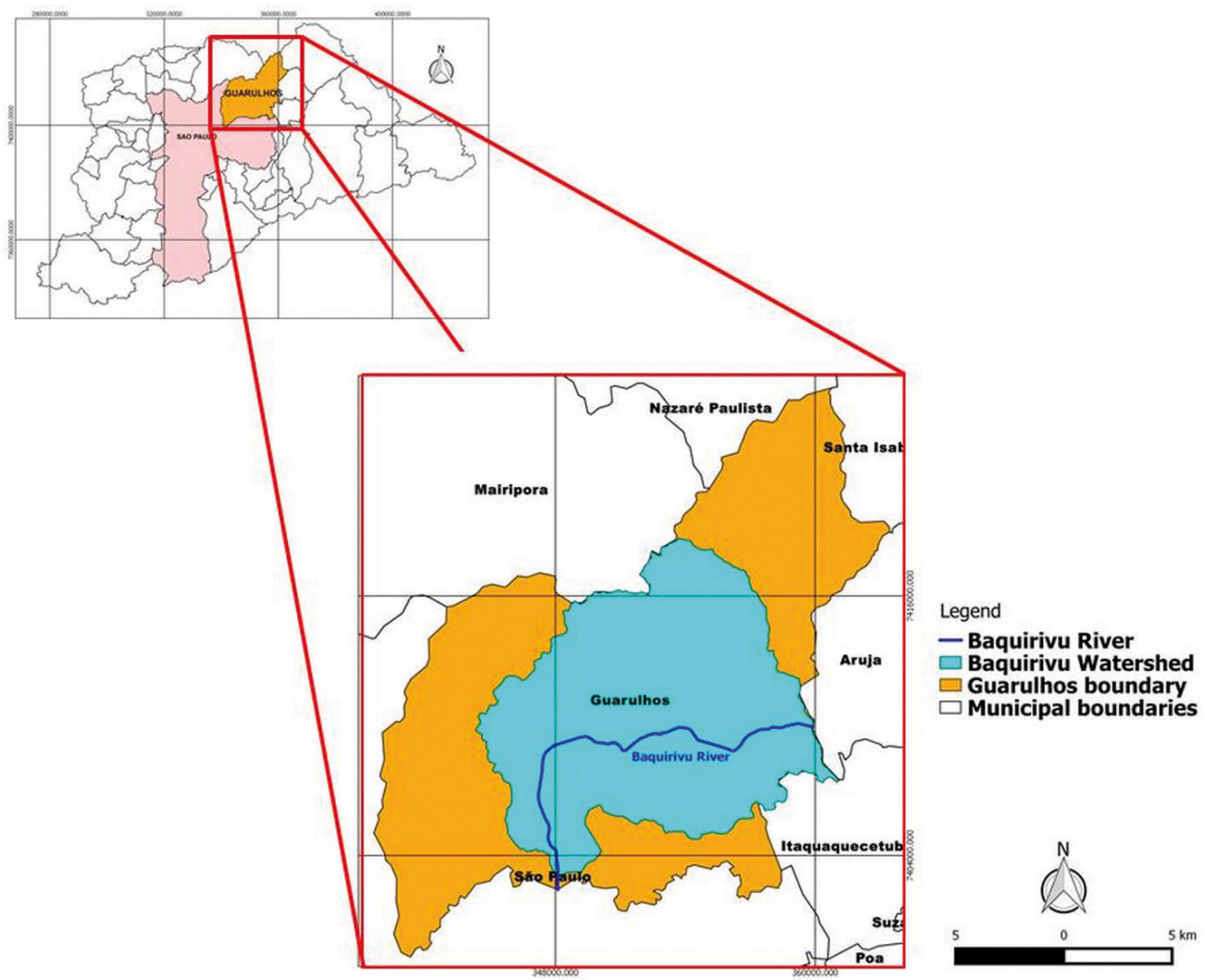

Figure 1. Location of BGRHB in the Guarulhos and Arujá municipalities.

Figura 1. Localização da BHRBG nos municípios de Guarulhos e Arujá.

Chart 1. Characteristics of the BGRHB physical space.

Quadro 1. Características do meio físico da BHRBG.

\begin{tabular}{|l|c|c|}
\hline & Northern portion & Southern portion \\
\hline Rock types & $\begin{array}{c}\text { Predominance of metamorphic rocks, such } \\
\text { as phyllites, iron formation, migmatites and } \\
\text { metabasic rocks; volcanic rocks and granites }\end{array}$ & Paleogene and alluvial sediments \\
\hline Landscape & Ridges, mounts, hillocks & Hills and fluvial plains \\
\hline Soils & Haplic cambisols, red-yellow latosols & Red-yellow argisols and gleisols \\
\hline Drainage & $\begin{array}{c}\text { Predominance of a high density dendritic } \\
\text { drainage pattern }\end{array}$ & $\begin{array}{c}\text { Wider valleys, sometimes with meandering } \\
\text { patterns, low density drainage }\end{array}$ \\
\hline
\end{tabular}




\subsection{Characterization of the land use}

According to Diniz \& Duarte (1996), land use in the BGRHB is very diversified thanks to the peculiar characteristics of the area, such as: proximity of the São Paulo Capital and location of São Paulo International Airport/Cumbica, Guarulhos Industrial Zone and the Presidente Dutra Highway. Therefore, not only high- to low-class residences are found, but also slums, varied types of industries, small rural properties and the Airport are located on the Baquirivu-Guaçu River banks.

In the region of the Baquirivu-Guaçu River basin the alluvial plains had a width varying between 200 and $400 \mathrm{~m}$. At each margin of the river clay and sand have been extracted from riparian wetlands for brick manufacturing and construction. Today, part of these areas is still preserved before reaching the São Paulo International Airport (Guarulhos / Cumbica). Around the Airport the wetlands were compacted and the river was channeled (Diniz \& Duarte, 1996).

In the present study, land use maps relative to 2010 and 2014 were generated for BGRHB by means of the Supervised Classification technique by Maximum Likelihood classifier which is based on statistical criteria of mean, variance and covariance (Crósta, 1993; Moreira, 2003; Camargo et al., 2007). To generate the 2010 map, a scene dated 25th October 2010 and taken by sensor AVNIR-2 (Advanced Visible and Near Infrared Radiometer type 2) was used. The sensor is part of the optical set of the ALOS satellite (Advanced Land Observing Satellite). For 2014, a scene from Landsat 8 dated 8th February 2014 was used, which was fused with a PAN band to reach a spatial resolution of $15 \mathrm{~m}$, which is very close to that of AVNIR-2 (10 $\mathrm{m})$.

Firstly, the scenes were pre-processed with ArcGIS 10 and georeferenced using control points taken from an orthorectified image (scene L5219076_07620040908 from Landsat 5). The next step was the radiometric correction to eliminate "noises", by means of the QUAC atmospheric correction module. This was performed by the program ENVI (version 4.7). After pre-processing, band composition was carried out with the objective of creating real color compositions in RGB format (Red, Green, Blue). Supervised classification was carried out using the resultant compositions for 2010 and 2014 by means of ENVI (version 4.7).

After classification it was defined the type and size sample by simple random sampling (Equation 1). Thus each mapped element would be selected by random way.
$n=N^{*} Z^{2 *} p^{*}(1-p) / Z^{2 *} p^{*}(1-p)+e^{2 *}(N-1) \quad$ (Eq. 1)

$\mathrm{n}$ : calculated sample; N: population; Z: standard normal variable associated with the confidence level (1.96); p: probability of the event; e: sampling error at a 95\% confidence level.

The next step after established the type and size of the sample, the accuracy evaluation was performed by index kappa (Equation 2) from control points $(n)$, measurement of differences and likelihood of agreement between the reference and classification data (Congalton, 1983; 1991; Lillesand et al., 2004; Richards \& Jia, 2006).

$k=N \sum X_{i i}-\sum X_{i+} X_{+i} / N^{2}-\sum X_{i+} X_{+i}$

Xii: observed agreement; $\mathrm{X} \mathrm{i}+$ and $\mathrm{X}+\mathrm{i}$ : marginal product; and $\mathrm{N}$ : total number of observed elements.

\subsection{Sewage Treatment Plants (STPS)}

At present, three of the Guarulhos sewage subsystems are in operation in BGRHB: Várzea do Palácio, São João and Bonsucesso (Fig. 2). In September 2010, STP São João went into operation and, according to SAAE (2013), the subsystem responds for $15 \%$ of the collected sewage, encompassing ca. 200 thousand inhabitants. The Bonsucesso sewage subsystem was inaugurated in December 2011 , and has treated $20 \%$ of the collected sewage, reaching 260 thousand inhabitants (SAAE, 2013). The Várzea do Palácio system started working in June 2014 and has treated 15\% of the collected sewage, encompassing ca. 200 thousand inhabitants. According to SAAE, with the addition of STP Várzea do Palácio, ca. 650 thousand inhabitants, approximately $53 \%$ of Guarulhos population, have benefitted from sewage treatment.

\subsection{Sample collecting, data analysis and legislation}

The data concerning the Baquirivu-Guaçu River water analyses do from 2011 to 2014 at points BQGU03150 and BQGU03850 were obtained from the superficial water reports from CETESB (Environmental Company of the State of São Paulo), including the nine parameters that compose the Water Quality Index (WQI) (CETESB, 2011, 2012, 2013 , 2014). These data were compared with the parameters established in Article 18 of Decree 8468/1976 (Brasil, 1977) and CONAMA 357/05 (Brasil, 2005).

The sampling points used in this study were BQGU03150, located on the bridge close to the 
Nippon Country Club on the Vados Highway, in the Arujá and Guarulhos municipal boundary (23⒉ $44^{\prime} 49^{\prime \prime}$ S and $\left.46^{\circ} 22^{\prime} 18^{\prime \prime} \mathrm{W}\right)$, and BQGU03850, located on the bridge on José Marques Prata Street, downstream the Guarulhos Penitentiary $\left(23^{\circ} 28^{\prime} 03^{\prime \prime} \mathrm{S}\right.$ and $\left.46^{\circ} 29^{\prime} 16^{\prime \prime} \mathrm{W}\right)$, as shown in figure 2 , which was elaborate with utilization of data vectors: municipality limit (1:50,000 scale), hydrography (1: 50,000 scale) and road network (1:5,000 scale).

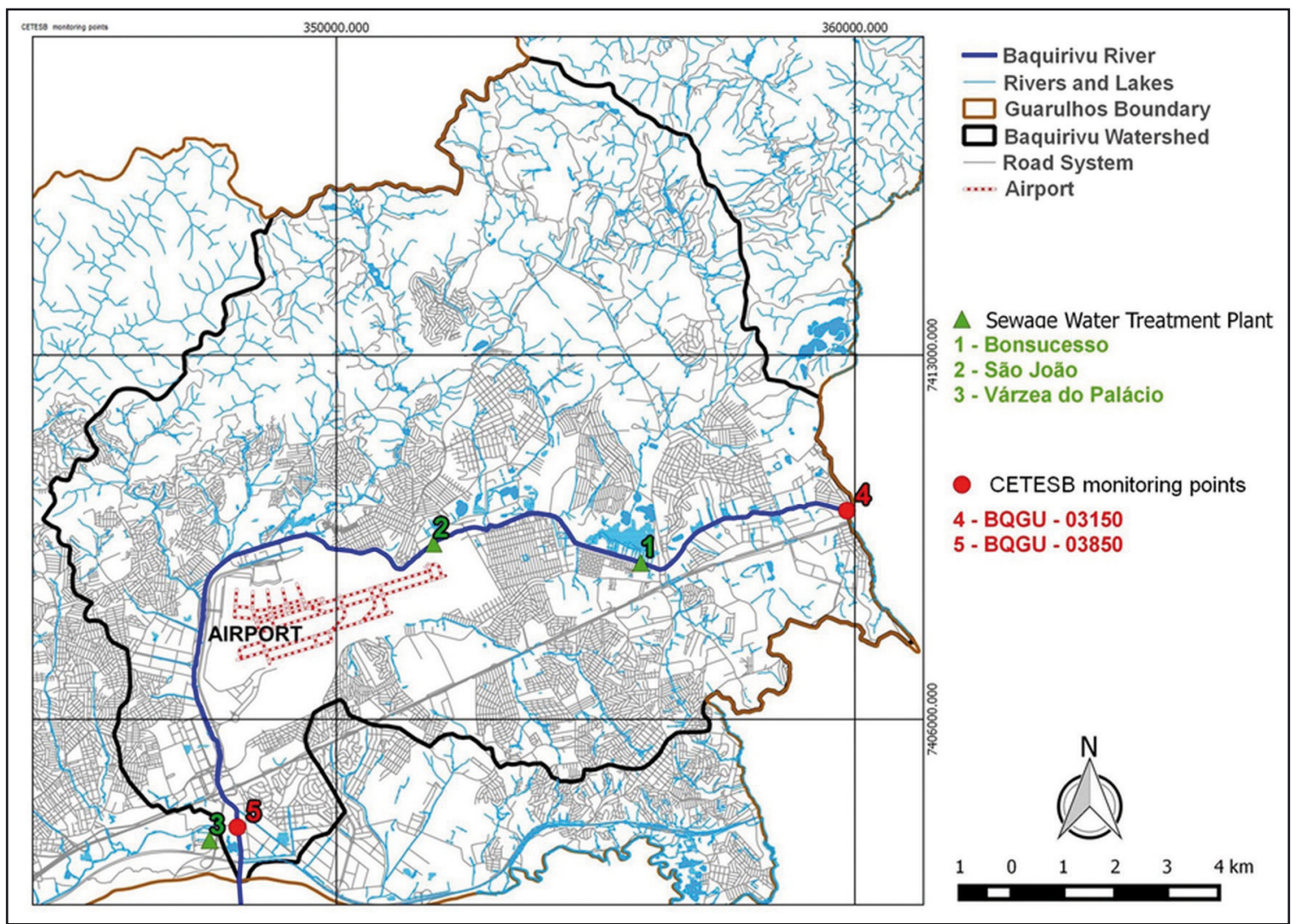

Figure 2. Location of the monitoring points BQGU03150 and BQGU03850 and STPs.

Figura 2. Localização dos pontos de monitoramento BQGU03150 e BQGU03850 e das ETEs.

\subsection{Water Quality Index (WQI)}

Since 1975, CETESB has used WQI as information on water quality of a water body. This index is composed of nine parameters: dissolved oxygen (DO), hydrogen potential $(\mathrm{pH})$, water temperature, biochemical oxygen demand (BOD), fecal coliforms (FC), total nitrogen (TN), turbidity (TU), total solid (TS) and total phosphorous (TP). The water quality variables mainly reflect the contamination of a water body caused by the launch of domestic sewage. The water temperature is a WQI variable that CETESB - Company of Environmental Sanitation Technology assumes as constant and equal to maximum quality. WQI is calculated according equation 3 by the weighed $\left(\mathrm{w}_{\mathrm{i}}\right)$ product of the nine parameters, and the bulk water quality can be classified using a 0 to 100 scale as showed in Table 1 (CETESB, 2015).

$$
\mathrm{WQI}=\prod_{\mathrm{i}=1}^{9} \mathrm{q}_{\mathrm{i}}^{\mathrm{w}_{\mathrm{i}}}
$$

Table 1. CETESB Classification of Water Quality Index. Tabela 1. Classificação CETESB para o Índice de Qualidade da Água.

\begin{tabular}{cc}
\hline Classification of WQI Value of WQI & WQI Value \\
\hline Very good & $80-100$ \\
Good & $52-79$ \\
Regular & $37-51$ \\
Bad & $20-36$ \\
Very bad & $0-19$ \\
\hline
\end{tabular}

\section{Results}

In relation to Maximum Likelihood Classifier technique applied to elaboration of land use maps, the orthorectified Landsat images showed Root Mean Square Errors (related to Ground Control Points) of $3.6 \mathrm{~m}$ and $5.2 \mathrm{~m}$ to the images of $10 / 25 / 2010$ and $02 / 08 / 2014$, respectively.

The evaluation of the accuracy of the maps by the kappa index was based on 375 control points (N) that represent characteristics recognized of land use classes that was selected by simple random sample and verified through the high spatial 
resolution of Google Earth Pro images (2016). The index showed the average probability of $82 \%$ of the categories mapped were classified correctly, which is a very good evaluation, according to Landis \& Koch (1977). These results show the high sensitivity of the map to classify the current characteristics of the land use.

According to the 2010 Census prepared by the Brazilian Institute of Geography and Statistics (IBGE, 2016) there were 184,196 residences in Baquirivu-Guaçu Basin. About 2,939 of these residences ( $2 \%$ of total) don't have sewage service; 5,909 (3\% of total) report have open Sewers; and 10,660 ( $6 \%$ of total) have accumulated garbage around the address.

Table 2 summarizes the main BGRHB land use classes and percentages analyzed in 2010 and 2014, when changes concerning vegetation cover are observed. There was an increase of $3.17 \%$ of the area covered by large-sized vegetation and $4.39 \%$ of exposed soil. On the other hand, there was a decrease of $7.56 \%$ of the area covered by small and medium vegetation, which may have occurred due to the replacement of grassland and/or savanna by agriculture; another hypothesis is the evolution of grassland and/or savanna to large-sized vegetation areas.

Table 2. BGRHB land use classes in 2010 and 2014.

Tabela 2. Áreas das classes de uso da terra da BHRBG em 2010 e 2014.

\begin{tabular}{lcc}
\hline \multicolumn{1}{c}{ Class } & $\begin{array}{c}\mathbf{2 0 1 0} \\
\text { Area (\%) }\end{array}$ & $\begin{array}{c}\mathbf{2 0 1 4} \\
\text { Area (\%) }\end{array}$ \\
\hline Urban area & 50.14 & 50.14 \\
Water body & 0.26 & 0.26 \\
Dense woody vegetation & 25.54 & 28.71 \\
Grassland/savanna vegetation & 21.22 & 13.66 \\
Exposed soil & 2.84 & 7.23 \\
\hline
\end{tabular}

The sewage treatment in Guarulhos municipality started on September $27^{\text {th }} 2010$, when STP São João went into operation, with a capacity to treat $15 \%$ of the sewage collected in the municipality, serving 195 thousand inhabitants distributed in 12 neighborhoods (PMG, 2014). The STP Bonsucesso went into operation on December $11^{\text {th }}$ 2011 , with a capacity to treat $20 \%$ of the collected sewage, covering 34 neighborhoods and a population of 260 thousand inhabitants. On July $30^{\text {th }}$ 2014, the STP Várzea do Palácio was inaugurated, with a capacity to treat $15 \%$ of the collected sewa- ge, serving 52 neighborhoods and a population of 195 thousand inhabitants, which raised to $50 \%$ the sewage treatment capacity. It is worth mentioning that, despite STP Várzea do Palácio being outside the study area, it receives sewage from neighborhoods within the study area.

At present, the organic charge treated in Guarulhos is $785 \mathrm{~kg} \mathrm{BOD} \mathrm{day}^{-1}$, with estimated 70,074 $\mathrm{kg} \mathrm{BOD} \mathrm{day}^{-1}$ of untreated polluting organic charge. This confers to the Guarulhos municipality urban population an indicator of sewage collection and treatability that equals 1.85 on a scale of zero to 10 (CETESB, 2014).

CETESB monitored every two months the quality of the waters of Baquirivu Guaçu river in BQGU 03150 and BQGU 03850 points, and from the nine parameters (temperature, $\mathrm{pH}, \mathrm{BOD}, \mathrm{TS}$, fecal coliforms, TP, TN, TU and DO), calculated the WQI for the two points, as can be seen in table 3 .

In relation to the average Water Quality Index (WQI) in the last four years, the data obtained at entrance and exit points in the Guarulhos municipality show that Arujá delivers water of Bad to Regular quality, whereas Guarulhos delivers to the Alto Tietê System water of Bad to Very bad quality (Fig. 3), which reflects an even larger drop in water quality of the Baquirivu-Guaçu River, which is a direct affluent of the Tietê River. It is worth pointing out that, due to the low rainfall indices in 2013 and 2014 in SPMR, WQI values worsened with the concentration of nutrients, such as total nitrogen and phosphorous, and BOD.

The Pareto analysis corresponding to point BQGU 03850 showed that the parameters that impacted WQI negatively were: fecal coliforms, FC (31\%), dissolved oxygen, DO (22\%), and biochemical oxygen demand, BOD (19\%). All these parameters reflect the significant presence of sewage in the effluents (Sperling, 2005). These parameters for point BQGU 03850, from 2011 to 2014, were close or a little higher than the mean values, as can be seen in table 4 . Regarding nutrients, carbon in the form of BOD, phosphorous and nitrogen, an uptrend is observed along the four years, indicating an increase in the generation of domestic sewage that is not treated, and consequently worsening of WQI. For point BQGU 03150, at the entrance of BGRHB, the parameters that caused a marked impact on water quality were: tolerant coliforms (46\%), BOD (19\%), and total phosphorous (18\%).

According to São Paulo State Decree \# 10755, dated November $22^{\text {nd }} 1977$ (Brasil, 1977), the waters of the Baquirivu-Guaçu River were ranked as Class 3 in all its extension. The legislation that establishes the legal limits of water physico-chemical 
Table 3. WQI values of BQGU 03150 and BQGU 03850 points from 2011 to 2014 Tabela 3. Valores de IQA dos pontos BQGU 03150 e BQGU 03850 de 2011 a 2014

\begin{tabular}{|c|c|c|c|c|c|c|c|c|}
\hline \multirow[t]{3}{*}{ month } & \multicolumn{4}{|c|}{ BQGU 03150} & \multicolumn{4}{|c|}{ BQGU 03850} \\
\hline & \multicolumn{3}{|c|}{ Year } & \multirow[b]{2}{*}{2014} & \multicolumn{4}{|c|}{ Year } \\
\hline & 2011 & 2012 & 2013 & & 2011 & 2012 & 2013 & 2014 \\
\hline jan & 33 & 41 & 43 & 30 & 31 & 31 & 28 & 12 \\
\hline mar & 50 & 54 & n.c.* & 27 & 18 & 16 & 17 & 14 \\
\hline may & 50 & 31 & 32 & 15 & 16 & 15 & 12 & 13 \\
\hline jul & 28 & 40 & 24 & 15 & 11 & 15 & 22 & 11 \\
\hline sep & 35 & 21 & 33 & 24 & 14 & 11 & 12 & 11 \\
\hline nov & 26 & 33 & 34 & 28 & 20 & 12 & 20 & 11 \\
\hline
\end{tabular}

*n.c.- not calculated (BOD was not analyzed)

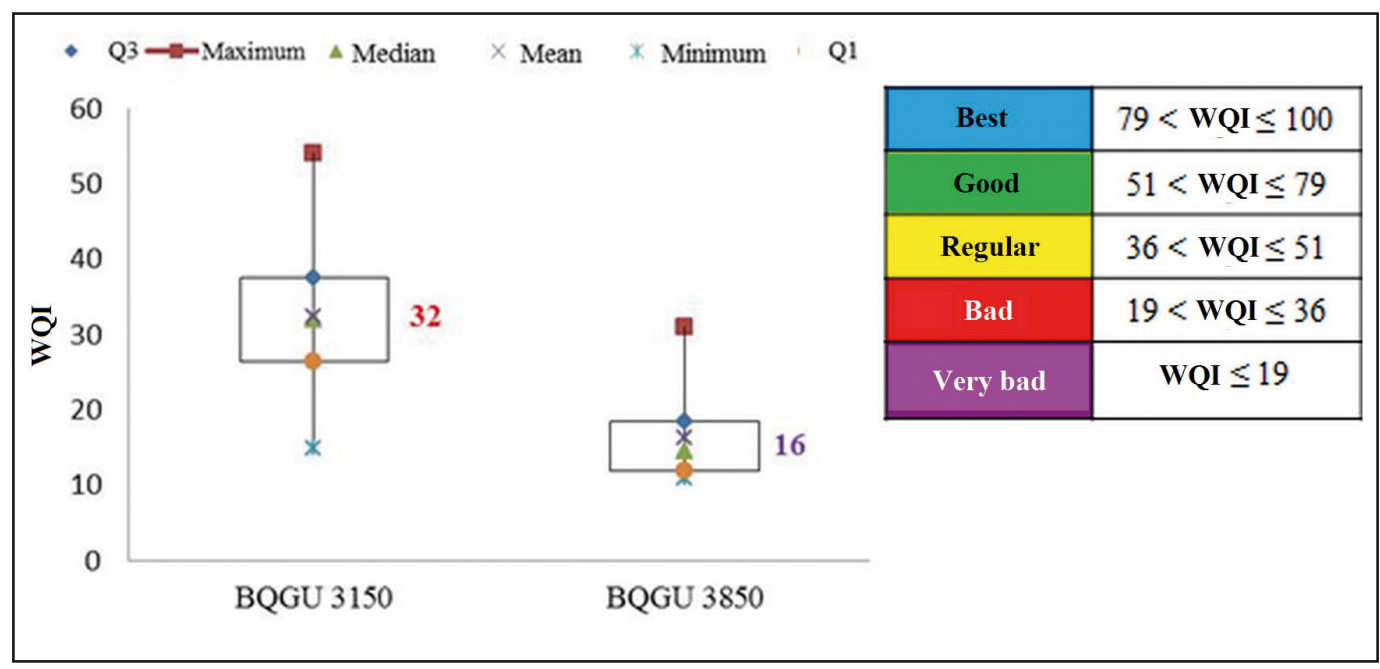

Figure 3. WQI Boxplot for points BQGU 03150 and BQGU 03850 (2011 to 2014).

Figura 3. Boxplot de IQA para os pontos BQGU 03150 e BQGU 03850 (2011 a 2014).

Table 4. Mean values of the physico-chemical and microbiologic parameters at BQGU 03850 from 2011 to 2014. Tabela 4. Valores médios dos parâmetros físico-químicos e microbiológico do ponto BQGU 03850 de 2011 a 2014.

\begin{tabular}{|c|c|c|c|c|}
\hline \multirow{2}{*}{$\log (\mathrm{FC})\left(\mathrm{UFC} .100 \mathrm{~mL}^{-1}\right)(\mathrm{n}=6)$} & 2011 & 2012 & 2013 & 2014 \\
\hline & $6.03 \pm 0.45$ & $6.18 \pm 0.42$ & $5.78 \pm 0.36$ & $6.99 \pm 0.09$ \\
\hline BOD $\left(\mathrm{mg} \mathrm{O}_{2} \cdot \mathrm{L}^{-1}\right)(\mathrm{n}=6)$ & $60 \pm 51$ & $64 \pm 41$ & $77 \pm 50$ & $73 \pm 46$ \\
\hline DO $\left(m g \cdot L^{-1}\right)(n=6)$ & $1.2 \pm 2.0$ & $1.3 \pm 2.0$ & $1.9 \pm 1.4$ & $1.9 \pm 1.4$ \\
\hline $\mathrm{TP}\left(\mathrm{mgL}^{-1}\right)(\mathrm{n}=6)$ & $1.01 \pm 0.86$ & $1.03 \pm 0.76$ & $1.41 \pm 0.69$ & $1.41 \pm 0.69$ \\
\hline TN $\left(m g . L^{-1}\right)(n=6)$ & $16.1 \pm 9.3$ & $22.4 \pm 12.5$ & $19.3 \pm 11.9$ & $19.2 \pm 11.8$ \\
\hline
\end{tabular}

Abbreviations: FC: fecal coliforms, BOD: biochemical oxygen demand, DO: dissolved oxygen, TP: total phosphorous and TN: total nitrogen. Abreviações: CF: coliformes fecais, DBO: demanda bioquímica de oxigênio, OD: oxigênio dissolvido, PT: fósforo total e NT: nitrogênio total.

and microbiologic parameters is CONAMA Resolution 357/05 (Brasil, 2005). Table 5 illustrates the percentages of non-conformity cases of the main parameters that compose WQI, in relation to the limits established by CONAMA Resolution 357/05 for both Baquirivu-Guaçu River points.

\section{Discussion}

The Baquirivu-Guaçu River Hydrographic Basin consists of areas with predominantly urban, industrial or industrial urban use, where about half of its area is composed by forest fragments and permeable land and important wetlands. Sato \& Andrade (2013) pointed out that in 2011 an incre- 
Table 5. Percentage of non-conformity cases in relation to the limits established by Resolution CONAMA 357/2005 for points BQGU03150 and BQGU03850 from 2011 to 2014.

Tabela 5. Porcentagem de casos de não conformidade das variáveis em relação aos limites da Resolução CONAMA 357/2005 para os pontos BQGU03150 e BQGU03850 de 2011 a 2014.

\begin{tabular}{rcccccc}
\hline \multicolumn{7}{c}{ Variable (n=24) } \\
(CONAMA 357/05 limit) \\
\hline Point & BOD & DO & TP & FC & pH & TU \\
& 10 & 4 & 0,15 & 4000 & $(6$ a 9 UpH $)$ & $(100$ NTU) \\
BQGU03150 & 87 & 17 & 96 & 88 & 0 & 0 \\
BQGU03850 & 91 & 83 & 96 & 100 & 0 & 29 \\
\hline
\end{tabular}

ase in woody-vegetation formation and decrease in grassland areas occurred due to the creation of the APA Cabuçu-Tanque Grande, Estação Ecológica do Tanque-Grande, Parque Natural Municipal da Cultura Negra, Sítio da Candinha and Parque Estadual do Itaberaba, which are environmental conservation units. Despite of such scenario of increasing dense woody vegetation, the urban area has been kept constant along the last years, representing a little more than half of the basin area. As can be seen in table 2 the main BGRHB land use classes and percentages analyzed in 2010 and 2014 were changes concerning vegetation cover. Furthermore, it is observed that the urban area remained unchanged and there was an increase in the exposed soil.

With the industrial urban setting observed in the region, the alternative to improve the quality of Baquirivu-Guaçu River would be the construction of sewage treatment plants. As above described, the STPs were constructed and put into operation starting from 2010. The results presented above for the period 2011-2014 should reflect an improvement in the water quality of the Baquirivu-Guaçu River, especially in point BQGU 03850. Unfortunately, it was not observed when the comparative results of the entry point (BQGU 03150) and the exit point (BQGU 03850) were analyzed. The low percentage of non-conformity cases for dissolved oxygen (DO) at point BQGU 03150, 17\% as observed in table 5 , is due to the fact that the STP located in the Arujá municipality is close to CETESB collecting point and the DO content in the effluent of the plant yields values greater than $5 \mathrm{mg} . \mathrm{L}^{-1}$, due to the aeration process at the exit of the STP (Saad et al., 2015). The high non-conformity values for FC and BOD at both points confirm the high organic matter content coming from the sewage, no matter the time of the year. $\mathrm{pH}$ values do not help the analysis of environmental impact on the water body, because all values fell within the limits established by legislation. Total phosphorous is another para- meter that is high above the values established by legislation, with $96 \%$ of non-conformity cases for this nutrient. At point BQGU 03150, as discussed by Saad et al. (2015), processing at the STP is aerated lagoon followed by decantation, that is a secondary treatment that is not efficient to remove phosphorous and nitrogen.

By means of a comparative temporal analysis of both points for each parameter that composes WQI, excepting temperature, the behavior of these variables through time at the entrance and exit of the Guarulhos municipality can be understood (Fig. 4). The mean values highlighted for BOD, DO, $\mathrm{TU}, \mathrm{TS}$ and FC parameters indicate a considerable worsening of the Baquirivu-Guaçu River waters at point BQGU 03850. The values of TN, TP and $\mathrm{pH}$ parameters both at the entrance and exit of the basin are close.

For FC parameters (Fig. 4H), the mean values for both points are well above the established by legislation. Regarding BOD (Figure 4F) there is a significant increase at point BQGU 03850, indicating a larger input of organic matter resultant from the high urban occupation in the region, as can be observed in the land use according table 2. Regarding dissolved oxygen (Fig. 4A), there is a significant difference, as reported before, because at point BQGU 03150 the values are within the established by legislation, whereas at the exit point, it is well below the minimum limit of $4.0 \mathrm{mg} . \mathrm{L}^{-1}$.

The parameter turbidity (Fig. 4E) indicates the presence of substances in suspension, that is finely divided solids in suspension or in colloidal state, and of microscopic organisms. The temporal analysis shows that the values at point BQGU 03150 are within the legislation specifications, whereas the exit values at point BQGU 03850 present a very large variation, with $29 \%$ of the values above the limit established by legislation (Tab. 5).

The excess of nutrients, specifically nitrogen and phosphorous, is mainly responsible for algae proliferation, which can result in eutrophication 

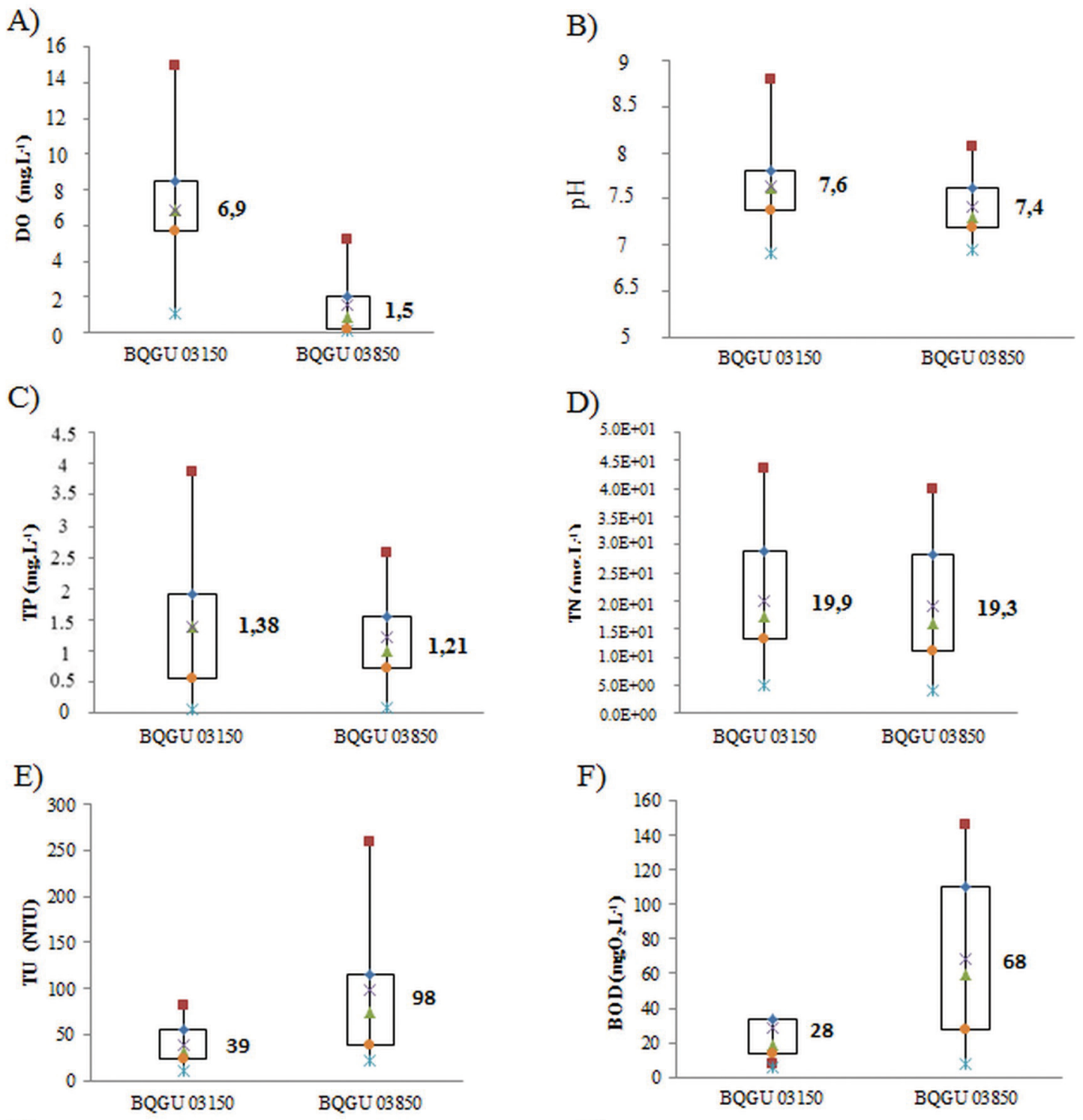

G)

$\mathrm{H})$
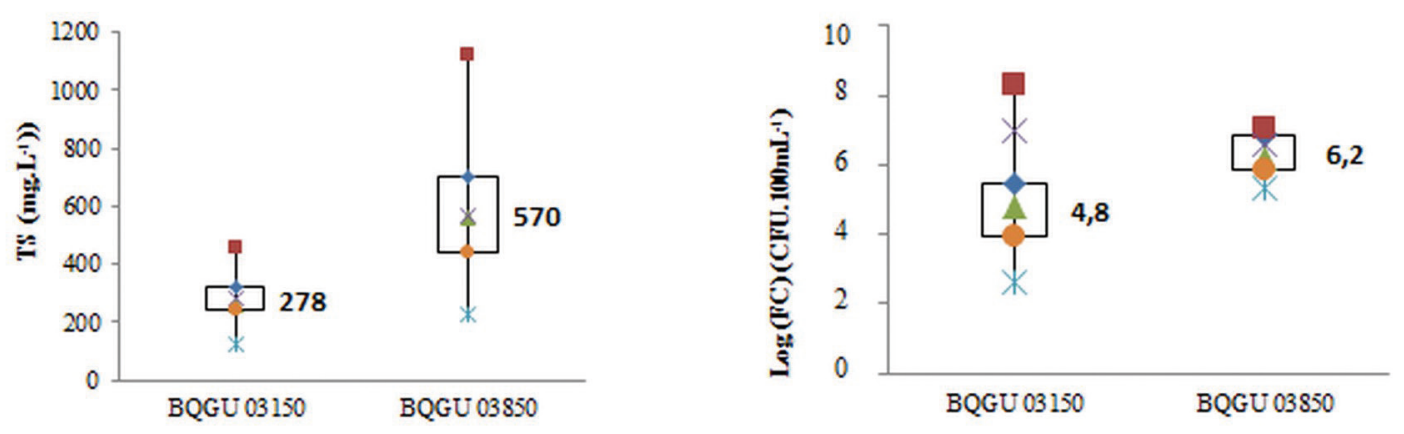

\section{Legend: •Q3 "Maximum $\triangle$ Median $\times$ Average $\times$ Minimum $\bullet Q 1$}

Figure 4. Boxplot for points BQGU03150 and BQGU03850 from 2011 to 2014 for the parameters: A) DO; B) pH; C) TP; D) TN; E) TU; F) BOD; G) TS; and H) Log [FC].

Abbreviations: DO (dissolved oxygen), pH (hydrogen potential), TP (total phosphorous), TN (total nitrogen), TU (turbidity), BOD (biochemical oxygen demand), TS (total solids) and FC(fecal coliforms).

Figura 4. Boxplot dos pontos BQGU03150 e BQGU03850 de 2011 a 2014 para os parâmetros: A) OD; B) pH; C) PT; D) NT; E) TU; F) $D B O ; G) S T ;$ e H) $\log (C F)$

Abreviações: OD (oxigênio dissolvido), pH (potencial hidrogeniônico), PT (fósforo total), NT (nitrogênio total), TU (turbidez), DBO (demanda bioquímica de oxigênio), ST (sólidos totais) and CF (coliformes fecais). 
of the water bodies (Esteves, 2011; Chislock et al., 2013). These two parameters vary in a similar way, when it comes to the high concentrations found in the Baquirivu-Guaçu River waters, as can be seen in figures $4 \mathrm{C}$ and $4 \mathrm{D}$.

According to Sato \& Andrade (2013), the cause of water degradation in BGRHB is associated with the intense urban expansion along the years, with no proper planning in terms of basic sanitation in the Arujá and Guarulhos municipalities.

Similar studies in Nigeria showed the impact of partially treated sewage effluent on the water quality of recipient Epie Creek in the Niger Delta area (Rim-Rukeh \& Agbozu, 2013). The water quality at four sampling points was determined using Malaysian Water Quality Index (WQI) and results show that, the water quality of Epie Creek belongs to Class IV with values that ranged between 31.0 and 51.9. Empirically, the water quality can be described as fairly polluted. Despite the WQI used to present some different parameters, such as chemical oxygen demand (COD), and not consider the total phosphorus (TP), the comparison in terms of water quality is valid and reflects results in a better water quality than that found in this work, but still insufficient for good quality water of the Nigerian river.

The results described by Kowalik et al. (2015) are quite different from those obtained by this work. They determine the effect of treated sewage discharged from a mechanical-biological sewage treatment plant, modernized in 2007-2008, on the water quality of the Bren River. On the basis of the data analysis it was found that pollutant concentrations in the treated sewage discharged into the Bren River did not exceed the values stated in the water permit. Although the parameters are within the limits established by polish legislation, the treated sewage affected 12 from among 17 analysed physicochemical indices in the Bren River, specially BOD and ammonium nitrate that caused a change of water quality class from I to II, and in case of phosphates a decline of ecological state from very good to below good. Only sporadically did not meet the requirements stated in the legislation regarding ammonium nitrogen concentrations in the winter-spring period. Despite a negative effect of the sewage treatment plant, the water quality state in the Bren River would be much worse if untreated municipal waste flowed into the receiving water.

Morrison et al. (2001) evaluated the performance of the STP in Keiskammahoek, a small town in the Eastern Cape, South Africa. The treatment system is the lagoon anaerobic / aerobic type wi- thout addition of chemicals, and the receiving body is Keiskamma River. Those authors observed a significant reduction in nitrogen, phosphorus and organic matter (COD), differently what was observed in this study. Despite this, it was recommended improvements in STP to reduce the levels of nutrients in accordance with local regulations.

Not always can the implementation of sewage treatment plants in hydrographic basins solve problems caused by pollutants of water bodies. Fontes \& Araújo (2008) assessed the effectiveness of the STP Ilhéus (Bahia State) in relation to the removal of total and fecal coliforms, and observed that, even if the STP reached the effectiveness index in coliform removal, it still launched a high percentage of such elements in the receiving body, the Cachoeira River estuary, in violation of the legislation. Even with up-to-date technology, which is the compact activated sludge STP, as described by Bastos (2012), the parameters fecal coliforms and BOD of the effluents launched in the Capivari Brook (Santa Catarina State) were within the acceptable limits, whereas nitrogen and phosphorous not always fell within such limits. Because the study area was used for recreation, the quality of the water worsened in holiday periods associated with rainy seasons.

The presence of illegal sewage connections still is a serious problem, even after the implementation of a STP. This was attested by Matsumoto \& Racanicchi (2002), who studied the influence of the implementation of a STP on the water quality of the Córrego da Mula, which belongs to the São José dos Dourados River hydrographic basin, in Santa Fé do Sul (São Paulo State). Organic matter content (BOD) was reduced from $180 \mathrm{mg} . \mathrm{L}^{-1}$ to values below $20 \mathrm{mg} . \mathrm{L}^{-1}$. However, according to the authors, illegal sewage connections to the rainfall network in the channelized segment prevented any significant improvement of the receiving body. Similar situation was found by Junior \& Carvalho (2010), who assessed the water quality in the microhydrographic basins of Gavanhery and Lambari Brooks, in the Getulina Municipality (São Paulo State). Besides the launching of illegal sewage, rural activity up- and downstream the STP also caused losses in water quality, due to diffused pollution.

An example of a STP can operate efficiently was described for the city of Kayseri in Turkey, which is serving for 800,000 population (Özkan et al., 2012). The STP, one of the big treatment plants in Turkey, showed efficiency removing $98 \%$ of the organic matter (BOD), 82 to $89 \%$ of the nitrogen, and 71 to $86 \%$ of the phosphorus, for the years 2006 - 2009. During the studied period, mean con- 
centrations in the effluent did not exceed the imposed limits, but sometimes, higher values were noticed for TN, and TP.

According to SAAE (2013), the size of the sewage network in Guarulhos municipality in December 2011 was 1,648.48 km, which served approximately $82 \%$ of the population. Up to now, even for 2014, after the implementation of the STPs, the results showed that no improvement was observed when it comes to E. coli, BOD, total phosphorous and dissolved oxygen, which are the parameters involved in sewage treatment. In the northern portion of the Guarulhos municipality, the water bodies have dendritic forms, constituting watershed areas, as highlighted in Chart 1. Unfortunately, the outcropping, good quality BGRHB water receives domestic sewage a few meters ahead of illegal occupations with no basic sanitation, which compromises both water quality and population's health (Rosa, 2014; Saad et al., 2015).

Besides the lack of basic sanitation, the Baquirivu-Guaçu River waters also undergo contamination of industrial origin. According to CETESB (2013), acute toxicity was detected in the Baquirivu-Guaçu River, due to dissolved copper, nickel, zinc and ammonia in concentrations capable of causing the observed toxic effects. This water body has presented acute toxicity since 2000, and an AIT study (Avaliação e Identificação da Toxicida$d e$ - Toxicity Assessment and Identification) has already been carried out at point BQGU03150 (CETESB, 2014). This study showed that the assessed toxic effect resulted from high zinc concentrations, as well as the presence of nonpolar organic compounds. Therefore, besides the high contribution of domestic sewage, contamination by industrial effluents also occurs (Sperling, 2005).

\section{Conclusions}

In this study, the contribution of Guarulhos municipality to the water quality of the Baquirivu-Guaçu River, by means of physico-chemical and microbiological analyses of the river waters was analyzed. After the analysis of the WQI parameters, it is concluded that the polluting source of the Baquirivu-Guaçu River waters is mainly anthropogenic, originated from the discharge of domestic sewage effluents in the water body with no proper treatment. The most impacted parameters were fecal coliforms, dissolved oxygen and BOD, followed by turbidity and total solids, revealing the large quantity of domestic sewage discharge. Within the Baquirivu-Guaçu River basin area, where $c a .70 \%$ of the municipality population is con- centrated, the present system has an operational capacity for $50 \%$ of the collected sewage, which represents $41 \%$ of the population. In the period covered by this study, only $35 \%$ of the collected sewage was treated, which corresponded to $29 \%$ of the population.

The analysis of land use evolution and water quality demonstrated the consequences of the inadequate process of urban growth in BGRHB and that the polluting domestic and industrial sources represent a considerable risk to water quality, showing that the sanitation works carried out up to now have not been effective in reducing the polluting charges launched in the waters of the Baquirivu-Guaçu River, which is the main affluent of the Alto Tietê System in the Guarulhos municipality.

Finally, it is important to emphasize the need for continuous monitoring of the water quality of the Baquirivu-Guaçu River in order to evaluate compliance with basic sanitation targets of the municipality of Guarulhos, so that in future the population has to create better public health conditions.

\section{References}

Andrade, M.R.M., Oliveira, A.M.S., Queiroz, W., Sato, S.E., Barros, E.J., Bragattini, G. \& Aleixo, A.A. 2008. Aspectos fisiográficos da paisagem guarulhense. In: Omar, E.E.H. (org.) Guarulhos tem História: Questões sobre a História natural, social e cultural. São Paulo: Ananda, p. 25-37.

Bastos, M.A. 2012. Avaliação da eficiência da ETE compacta e sua influência no Ribeirão Capivari em Ingleses, Florianópolis/SC. Florianópolis, 48p. Dissertação de Mestrado, Programa de Pós-Graduação em Ciência e Tecnologia Ambiental, Centro de Ciências Tecnológicas da Terra e do Mar, Universidade do Vale do Itajaí.

Brasil. 1977. Decreto no 10.755 de 22 de novembro de 1977. Dispõe sobre o enquadramento dos corpos de água receptores na classificação prevista no Decreto no 8.468 , de 8 de setembro de 1976, e dá providências correlatas. Available at: <http://pnqa. ana.gov.br/Publicao/Decreto $\% 20$ n $\%$ C2\%BA\%20 $10.755 \% 20 \mathrm{de} \% 2022 \% 20 \mathrm{de} \% 20$ novembro $\% 20$ de\%201977.pdf> Accessed on 18th October 2015.

Brasil. 2005. Resolução CONAMA 357 de 17 de março de 2005. Dispõe sobre a classificação dos corpos de água e diretrizes ambientais para o seu enquadramento, bem como estabelece as condições e padrões de lançamento de efluentes, e dá outras providências. Available at: <http://www.mma.gov.br/port/ conama/res/res05/res35705.pdf> Accessed on 19th October 2015.

Camargo, F.F., Pereira, G., Moraes, E.C., De Oliveira, L.G.L. \& Adami, M. 2007. Multi-temporal analysis of urban evolution and its influence on the thermal field change in the Greater São Paulo for the years 1985, 1993 
and 2003. <http://marte.dpi.inpe.br/col/dpi.inpe. br/sbsr\%4080/2006/11.18.00.05/doc/51275134. pdf $>$ Accessed on $25^{\text {th }}$ September 2016.

Campos, D.C. 2011. Inundações: Problemas ou Fenômenos Naturais? A Ocupação das Várzeas dos Principais Rios no Alto Tietê e a Reprodução deste Modelo Urbano na Bacia do Rio Baquirivu Guaçu, Guarulhos (SP). Guarulhos, 224p. Dissertação de Mestrado, Programa de Pós-Graduação em Análise Geoambiental, Universidade Guarulhos.

CETESB. Companhia de Tecnologia de Saneamento Ambiental. 2011. Relatório de Qualidade das Águas Interiores do Estado de São Paulo. Available at: <http://aguasinteriores.cetesb.sp.gov.br/publicacoes-e-relatorios/> Select 2011 "Relatório". Accessed on 18th October 2015.

CETESB. Companhia de Tecnologia de Saneamento Ambiental. 2012. Relatório de Qualidade das Águas Interiores do Estado de São Paulo. Available at: <http://aguasinteriores.cetesb.sp.gov.br/publicacoes-e-relatorios/> Select 2012 "Relatório". Accessed on 18th October 2015.

CETESB. Companhia de Tecnologia de Saneamento Ambiental. 2013. Relatório de Qualidade das Águas Interiores do Estado de São Paulo. Available at: <http://aguasinteriores.cetesb.sp.gov.br/publicacoes-e-relatorios/> Select 2013 "Relatório Parte 1". Accessed on 18th October 2015.

CETESB. Companhia de Tecnologia de Saneamento Ambiental. 2014. Relatório de Qualidade das Águas Interiores do Estado de São Paulo. Available at: $<$ http://aguasinteriores.cetesb.sp.gov.br/publicacoes-e-relatorios/> Select 2014 "Relatórios Parte 1 Qualidade das Águas Superficiais”. Accessed on 18th October 2015.

CETESB. Companhia de Tecnologia de Saneamento Ambiental. 2015. IQA, Índice de Qualidade das Águas. Available at: <http://aguasinteriores.cetesb.sp.gov. br/wp-content/uploads/sites/32/2013/11/02. pdf $>$ Accessed on 18th October 2015.

Chislock, M.F., Doster, E., Zitomer, R.A. \& Wilson, A.E. 2013. Eutrophication: Causes, Consequences, and Controls in Aquatic Ecosystems. Nature Education Knowledge 4(4): 10.

Congalton, R.G.; Oderwald, R.G.; Mead, R.G. 1983. Assessing Landsat classification accuracy using discrete multivariate statistical techniques. Photogrammetric Engineering and Remote Sensing, 49(12): 16711678.

Congalton, R. G. 1991. A review of assessing the accuracy classifications of remotely sensed data. Remote Sensing Environment, 37: 35-46.

Crosta, A.P. 1993. Processamento Digital de Imagens de Sensoriamento Remoto. Campinas: IG/UNICAMP, 170 p.

Diniz, H.N. \& Duarte, U. 1996. Caracterização geológica e hidrogeológica da Bacia Hidrográfica do Rio Baquirivu-Guaçu, na região de Guarulhos, SP. Revista Geociências UnG, 1 (3): 51-61.

Esteves, F.A. 2011. Fundamentos de Limnologia. 3a‥ ed., Rio de Janeiro: Editora Interciência. 790p.
Fontes, I. B. M. \& Araújo, Q. R. 2008. Eficiência na remoção de coliformes na estação de tratamento de esgoto de Ilhéus (Bahia). Geografia, 17: 127-136.

Google Earth Pro. 2016. Information obtained from Google's, Available at: <www.google.com> Accessed on $21^{\text {th }}$ September 2016.

IBGE (Brazilian Institute of Geography and Statistics). Available at: <http//www.ibge.gov.br> Accessed on $21^{\text {th }}$ March 2016.

Junior, F.R. \& Carvalho, S.L. 2010. Avaliação da qualidade das águas na microbacia hidrográfica dos Córregos Gavanhery e Lambari no município de Getulina, SP. HOLOS Environment, 10: 180-194.

Kowalik, T., Bogdał, A., Borek, L and Kogut, A. 2015. The effect of treated sewage outflow from a modernized sewage treatment plant on water quality of the Breń river. Journal of Ecological Engineering, 16(4): 96-102.

Landis, J.R. \& Koch, G.G. 1977. The measurement of observer agreement for categorical data. Biometrics, 33: 159-154.

Lillesand, T.M., Kiefer, R.W. \& Chipan, J. W. 2004. Remote sensing and interpretation. $5^{\text {th }}$ ed. Madison: Wiley, $763 \mathrm{p}$.

Matsumoto, T. \& Racanicchi, R.M.Z.V. 2002. Influence of the implantation of a sewage treatment plant on the quality of a receiving body in an urban area. In: VI Simpósio Ítalo Brasileiro de Engenharia Sanitária e Ambiental (SIBESA), Vitória (ES), Brasil.

Moreira, M.A. 2003. Fundamentals of remote sensing and application methods. Viçosa, Editora UFV, 307p.

Morrison, G., Fatoki, O.S., L Persson, L. \& Ekberg, A. 2001. Assessment of the impact of point source pollution from the Keiskammahoek Sewage Treatment Plant on the Keiskamma River - pH, electrical conductivity, oxygen- demanding substance (COD) and nutrients. Water SA, 27(4): 475-480.

Özkan, O., Oğuz, M. \& Özdemir, Ö. 2012. Characterization and assessment of a large-scale domestic advanced wastewater treatment plant in Turkey. Environ Monit Assess, 184: 5275-5281.

PMG - Prefeitura Municipal de Guarulhos - Secretaria de Meio Ambiente. 2014. Estações de Tratamento de Esgoto - Available at: <http://www.guarulhos. sp.gov.br/ pagina/tratamento-de-esgoto> Accessed on $19^{\text {th }}$ September 2015.

Richards, J.A. \& Jia, X. 2006. Remote sensing digital image analysis: an introduction. New York: Springer-Verlag, 439p.

Rim-Rukeh, A. \& Agbozu, I.E. 2013. Impact of partially treated sewage effluent on the water quality of recipient Epie Creek Niger Delta, Nigeria using Malaysian Water Quality Index (WQI). Journal of Applied Sciences and Environmental Management, 17 (1): 5-12.

Rosa, A. 2014. Degradação ambiental da bacia hidrográfica do Córrego Taquara do Reino, Município de Guarulhos (SP): reflexos na qualidade da água. Guarulhos, SP. Guarulhos, 71 p. Dissertação de Mestrado, Programa de Pós-Graduação em Análise Geoambiental, Universidade Guarulhos. 
Saad, A.R., Martinez, S.S., Goulart, M.E., Semensatto, D., Vargas, R.R. \& Andrade, M.R.M. 2015. Efeitos do uso do solo e da implantação da estação de tratamento de esgoto sobre a qualidade das águas do rio Baquirivu-Guaçu, Região Metropolitana de São Paulo. Revista Brasileira de Recursos Hídricos, 20(1): 147-156.

SAAE. Serviço Autônomo de Água e Esgoto de Guarulhos. 2013. Sistema de esgoto. Available at: http:// www.saaeguarulhos.sp.gov.br/. Accessed on $19^{\text {th }}$ September 2015.

Sato, E.S \& Andrade, M.R.M. 2013. Correlação da evolução temporal do uso da terra e a qualidade das águas

Manuscrito 598

Editores: Nina Simone Vilaverde Moura \& Paulo A.

Souza. superficiais da Bacia do rio Baquirivu-Guaçu, nos municípios de Arujá e Guarulhos (SP). Revista Geociências UnG, 12 (1): 26-48.

Sperling, M. von. 2005. Introdução à Qualidade das Águas e ao Tratamento de Esgotos. Belo Horizonte: UFMG, 452p.

Tundisi, J.G., Braga, B. \& Rebouças, A.C. 2006. Os recursos hídricos e o futuro: síntese. In: Rebouças, A.C., Braga, B. \& Tundisi, J.G. (Eds.), Águas doces no Brasil: capital ecológico, uso e conservação. $3^{\text {a }}$ ed. São Paulo: Escrituras, 748p. 
